\title{
1,2,4-TRIAZOLE DERIVATIVES IN MEDICINE AND PHARMACY AND APPLICATION PROSPECTS
}

\author{
TIP VE ECZACILIK ALANINDAKI 1,2,4-TRİAZOL TÜREVLERİ VE UYGULAMA \\ ÖNERILLERं
}

\section{Yurii G. SAMELIUK ${ }^{1, *} \mathbb{D}^{D}$, Fadi AL ZEDAN $^{2}$ (D) Tetyana M. KAPLAUSHENKO $^{3}$}

${ }^{1}$ Zaporizhzhia State Medical University, Faculty of Pharmacy, Department of Physical and Colloidal Chemistry, 69000, Ukraine

${ }^{2}$ Zaporizhzhia State Medical University, Faculty of Pharmacy, Drug Technology Department, 69000, Ukraine

${ }^{3}$ Zaporizhzhia State Medical University, Medical College, 69000, Ukraine

\begin{abstract}
Objective: Development of methods for the synthesis, studies of chemical, physico-chemical and biological properties of 1,2,4-triazole derivatives, in particular compounds with heterocyclic scaffolds and complex compounds as potential biologically active substances.

Result and Discussion: In this review, 40 scientific papers reporting the properties of 1,2,4-triazole derivatives were evaluated. Each class of compounds described in the review was reported with the prospect of forming the direction for further research.Because of there is no enough studies about biological action of 1,2,4-triazole derivatives in human, it encourages further research.
\end{abstract}

Keywords: Biological activity, bibliosemantic method, organic synthesis, 1,2,4-triazole

$\ddot{O Z Z}$

Amaç: 1,2,4-triazol türevlerinin,özellikle heterosiklik iskelete sahip ve biyolojik olarak aktif bileşiklerin, sentezi, kimyasal, fizikokimyasal ve biyolojik özelliklerinin incelenmesi için yöntemlerin geliştirilmesi.

Sonuç ve Tartışma: Bu derlemede, 1,2,4-triazol türevlerinin özelliklerinin bildirildiği 40 bilimsel makale değerlendirilmiştir. Verilenher bileşik sınıfi gelecekteki çalışmalara yön verecek şekilde bildirilmiştir.1,2,4triazol türevlerinin insandaki biyolojik etkileri hakkında yeterli çalışma olmaması, bu alanda daha fazla çalışma yapılmasını teşvik etmektedir.

Anahtar Kelimeler: Biyolojik aktivite, bibliyosemantik yöntem, organik sentez 1,2,4-triazol

\footnotetext{
* Corresponding Author/Sorumlu Yazar: Yurii Sameliuk

e-mail / e-posta: sameluk_yurii @ukr.net, Phone / Tel.: +38066424 1204
} 


\section{INTRODUCTION}

Modern world pharmaceutical science is based on the following main areas: search for new original drugs (including synthesis of biologically active compounds and their biological screening), manufacture (selection and development of dosage form, development of production methods), standardization (development of quality control methods for the substance), preclinical and clinical trials. Also one of the main directions is marketing research. All of the above allow the introduction of new original drugs in general pharmaceutical and medical practice.

To implement the project of drug development, first of all it is necessary to determine the matrix for further stages of implementation. It is for this purpose that we conducted this literature review.

The synthetic school of 1,2,4-triazole derivatives was created by Professor of Zaporizhzhia State Medical University Yevhen Hryhorovych Knysh. He has developed and introduced many drugs derived from 1,2,4-triazole into medical, pharmaceutical and veterinary practice. As followers of the school of triazoles under the leadership of Professor of Zaporizhzhia State Medical University Kaplaushenko Andriy Hryhorovych, scientists of the Department of physical and colloidal chemistry carry out research in this synthetic direction.

This review aims to systematize the literary data on 1,2,4-triazole derivatives and to determine the further vector of scientific studies.

Today, 1,2,4-triazoles synthesized by scientists of Zaporizhzhia State Medical University are considered promising research directions. This is justified by the simplicity of synthesis, the availability of reagents, high biological activity and low molecular toxicity.

Also, the modern pharmaceutical and medical community pays considerable attention to coordination complexes, as the processes of coordination, dissociation of complexes and intercomplex rearrangement are important in the biological processes of the organism. That is why highly effective mono- and disubstituted 1,2,4-triazoles at the 4th and 5th positions of the nucleus were chosen as objects of the research. The article is also considered promising options for obtaining coordination compounds based on 1,2,4-triazoles, which in the future will allow to obtain new highly efficient biologically active complexes. According to the authors, the analysis will allow to combine bioactive fragments of triazoles into coordination structures, which may have a greater biopotential.

We reviewed 40 scientific papers for a more detailed look at the triazole research aspects. The review includes the results of scientific works which describe molecules that are not difficult to obtain, have high results of biological action, and recommended by the authors for further research.

\section{RESULT AND DISCUSSION}

\section{Synthesis and Some Pharmacological Properties of 1,2,4-triazole Derivatives}


Scientists [1] synthesized a series of five-membered heterocyclic systems (Fig. 1) containing three heteroatoms from the parent compound (Felbinac) [1]. When designing the molecules of the starting compounds, the aromatic structure of biologically active compound (hereinafter BAC) of Felbinac was preserved. The carboxy group was synthetically converted to the nucleus of 1,2,4-triazole and further modified to create anti-inflammatory compounds drugs. Biological activity was studied in laboratory animals. The carrageenan model was chosen to determine the anti-inflammatory effect. The biological effect of the synthesized compounds was compared with ibuprofen and yield matrix after 120 minutes and 180 minutes. The test compounds showed excellent anti-inflammatory activity. Low rates of acute toxicity of compounds are a prospect for further research.<smiles>[R]C(O)Cc1ccc(-c2ccccc2-c2ccc(CC(=O)NNC(=O)Cc3ccc(-c4ccccc4)cc3)cc2)cc1</smiles>

Figure 1. Synthesis 1,2,4-triazole derivatives of Felbinac [1]

In the study conducted by the authors [2], a series of new systems with condensed heterocycles were synthesized. The compounds were synthesized from the initial 4-(4-X-phenylsulfonyl)phenyl)-4H1,2,4-triazol-3-thiols (Fig. 2, where $\mathrm{X}=\mathrm{H}, \mathrm{Cl}, \mathrm{Br}$ ).

To synthesize a series of new compounds, the initial triazoles were subjected to interaction, in the presence of ethanoic acid and its anhydride, with 4-fluorobenzaldehyde, $\alpha$-chloroethane acid, and sodium acetate.

The corresponding ethanones were obtained by treating the initial triazoles with 2-bromo-4'fluoroacetophenone. Cyclic forms of 1,2,4 triazoles (at the 3 and 2 positions of the heterocyclic nucleus) were obtained by cyclizing S-alkylated 1,2,4-triazoles in $\mathrm{H}_{2} \mathrm{SO}_{4}$ medium, at $0{ }^{\circ} \mathrm{C}$.

The composition of the synthesized compounds was confirmed by elemental analysis. The structure was confirmed by mass spectrometry, IR, ${ }^{1} \mathrm{H}\left({ }^{13} \mathrm{C}\right)$-NMR. The synthesized compounds demonstrated antimicrobial and antifungal activity [2].

The scientific publication of authors [3] (Fig. 3) describes the synthesis of new S-substituted 1H3-R-5-thio-1,2,4-triazoles on cancer cells of the HT29 line. Among all synthesized structures, 55.7 TZ was developed as a possible inhibitor of phospholipid-dependent kinase 1, which exhibits significant cytotoxic activity against HT29. 55.7 TZ cells along with two other BACs (ciphers $53.7 \mathrm{TZ}$ and 3A.7 
TZ), led to a significant delay in the cell cycle. This study reveals the prospects for the development of new agents containing a 5-thio-1,2,4-triazole framework with antiproliferative activity.

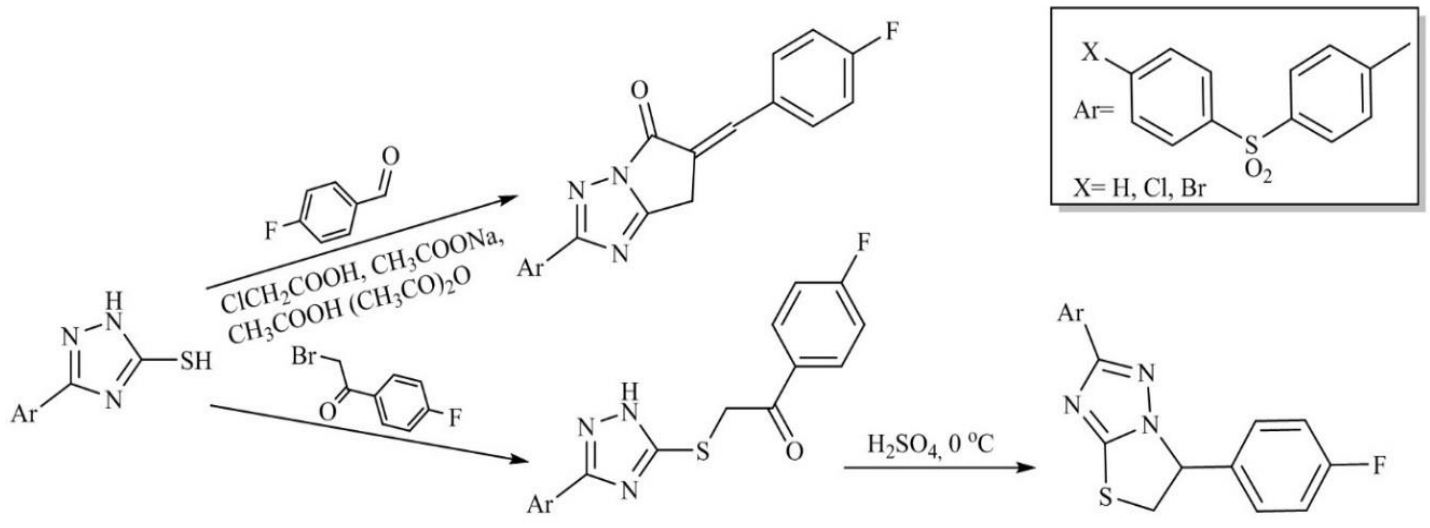

Figure 2. Synthesis scheme of cyclocondensation of 3-thio-1,2,4-triazoles [2]

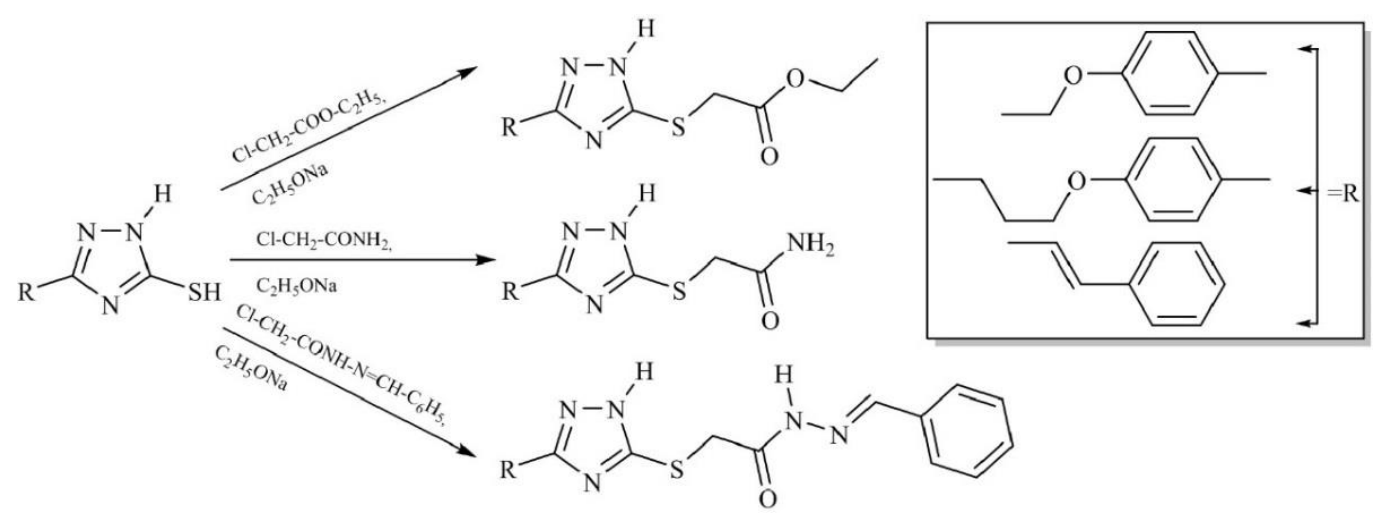

Figure 3. Modification of 1,2,4-triazoles at the S-position [3]

Bacterial resistance to antimicrobials requires new antimicrobial BACs that are more effective and less toxic [4]. Triazole and thiazoleylidenhydrazides are considered the key matrices in medical chemistry. The derivatives of 1,2,4-triazole synthesized by the researchers [4] (Fig. 4) showed an effect similar to ciprofloxacin. Antimicrobial enhancement is also expressed in some compounds against Listeria monocytogenes. Derivatives have pronounced minimum inhibitory concentration (MIC) values. Compounds with fluorophenyl, bromphenyl, nitrophenyl, and methoxyphenyl substituents strongly inhibited growth of Pseudomonas aeruginosa. The synthesized BACs were screened in silico for their absorption, distributive, metabolic, elimination, and toxicity properties. Based on the results of virtual screening, the authors [4] concluded that thiazolyl-triazoleylidenhydrazide with a hydroxyphenyl substitute is the best candidate for a leader compound that exceeds the action of ciprofloxacin [4]. 


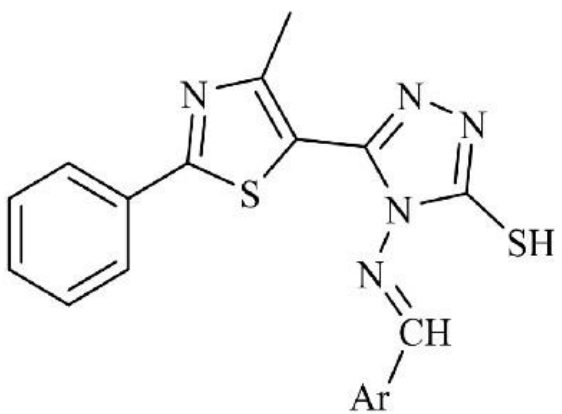

$\mathrm{Ar}=$-2,4-diCl-phenyl; -2,6-diCl-phenyl; -2,3-diCl-phenyl; -3-di-phenyl; -4-Br-phenyl; -4-F-phenyl; - 2-OH-phenyl; -3-OH-phenyl; -4-OH-phenyl; -3- $\mathrm{NO}_{2}$-phenyl; -4- $\mathrm{NO}_{2}$-phenyl; -2- $\mathrm{OCH}_{3}$-phenyl; $-3-\mathrm{OCH}_{3}$-phenyl; -2-thienyl; $-4\left(\mathrm{CH}_{3}\right)_{2} \mathrm{~N}$-phenyl;

Figure 4. Structures of new thiazolyltriazole Schiff bases [4]

The authors [5] showed that $\mathrm{Bi}(\mathrm{NO} 3) 3 \cdot 5 \mathrm{H} 2 \mathrm{O}$ or $\mathrm{ZrCl} 4$ catalyzed the opening of the nucleophilic ring of dicyanooxyrans together with 5-thio-1,2,4-triazole-3-phenyl. The catalysts are inexpensive, highly efficient, and can be used repeatedly (Fig. 5). This study is promising for further identification of biologically active agents, since the combination of several electron-donor groups in one structure at the same time can lead to an increase in the cytoprotective effect.

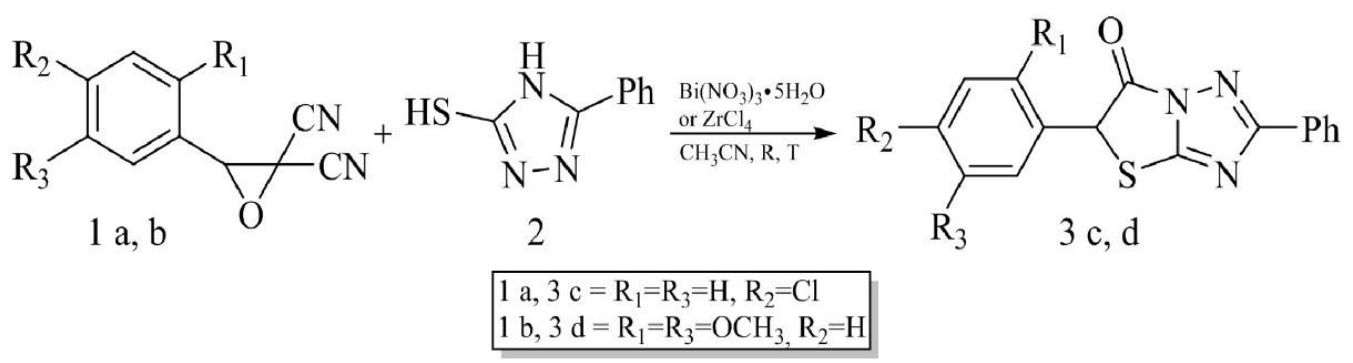

Figure 5. Condensation reaction of 5-mercapto-3-phenyl-4H-1,2,4-triazole [5]

The therapeutic use of 1,2,4-triazole prompted the authors [6] to create new BACs. Two series of S-substituted derivatives were synthesized and their biological potential was evaluated. The initial thiol was transformed by the action of an alkyl halide in a neutral solvent (Fig. 6). Intermediate electron acceptors were synthesized by the interaction of $\mathrm{N}$-substituted alkyl/arylamines and 2-bromoacetyl bromide under dynamic $\mathrm{pH}$ control. The structures were established using IR, EIMS, ${ }^{1} \mathrm{H}$, and ${ }^{13} \mathrm{C}$ NMR spectral methods. Most of the synthesized derivatives were found to be potent inhibitors of the enzyme glucosidase and are even better than the commercial analog of acarbose.

Targeted changes in the structure significantly affected the results of bioactivity. Synthesized BACs can be considered for drug development programs for the treatment of type II diabetes. 
The authors [7] synthesized a new matrix based on 1,3-bi-1,2,4-triazole-5,5-diamine (Fig 7.). The synthesized compound is characterized by various analysis methods, such as IR, NMR spectrometry, and HPLC [7].

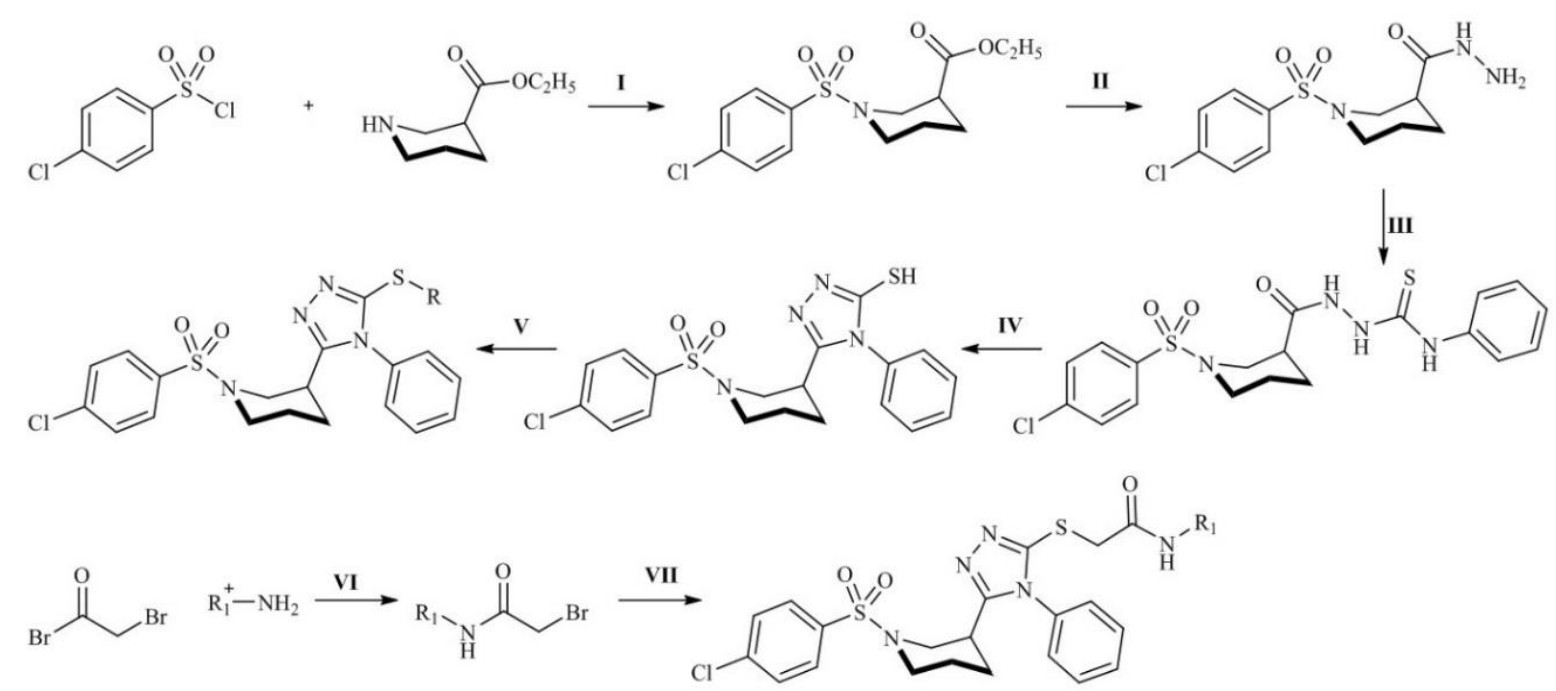

Reagents \& conditions: (I) $5 \% \mathrm{Na} 2 \mathrm{CO} 3$ soln. / H2O / pH 9\{10/ stirring for $3\{4$ h. (II) N2H4 / MeOH / reuxing for $5\{6$ h. (III) Phenyl isothiocyanate / $\mathrm{MeOH} /$ reuxing for $3\{4 \mathrm{~h}$. (IV) $10 \% \mathrm{NaOH} /$ reuxing for $2\{3 \mathrm{~h}$. (V) DMF / NaH / stirring for $2\{3 \mathrm{~h}$. (VI) Aq. $5 \% \mathrm{Na} 2 \mathrm{CO} 3 /$ stirring for $30 \mathrm{~min}$. (VII) DMF $\mathrm{NaH} /$ stirring for $2\{3 \mathrm{~h}$.

$\mathbf{R}=\mathrm{C}_{2} \mathrm{H}_{5}, \mathrm{n}-\mathrm{C}_{3} \mathrm{H}_{7}$, iso- $\mathrm{C}_{3} \mathrm{H}_{7}, \mathrm{n}-\mathrm{C}_{4} \mathrm{H}_{9}$, sec- $\mathrm{C}_{4} \mathrm{H}_{9}, \mathrm{n}-\mathrm{C}_{5} \mathrm{H}_{11}$, sec- $\mathrm{C}_{5} \mathrm{H}_{11}, \mathrm{n}-\mathrm{C}_{7} \mathrm{H}_{15}, \mathrm{n}-\mathrm{C}_{8} \mathrm{H}_{17}, \mathrm{C}_{3} \mathrm{H}_{5}$ $\mathbf{R}_{1}=\mathrm{C}_{6} \mathrm{H}_{5}, \mathrm{CH}_{2}-\mathrm{C}_{6} \mathrm{H}_{5}, 2-\mathrm{CH}_{3}-\mathrm{C}_{6} \mathrm{H}_{5}, 3-\mathrm{CH}_{3}-\mathrm{C}_{6} \mathrm{H}_{5}, 4-\mathrm{CH}_{3}-\mathrm{C}_{6} \mathrm{H}_{5}, 2-\mathrm{C}_{2} \mathrm{H}_{5}-\mathrm{C}_{6} \mathrm{H}_{5}, 4-\mathrm{C}_{2} \mathrm{H}_{5}-\mathrm{C}_{6} \mathrm{H}_{5}, 2-\mathrm{OC}_{2} \mathrm{H}_{5}-\mathrm{C}_{6} \mathrm{H}_{5}, 4-\mathrm{OC}_{2} \mathrm{H}_{5}-\mathrm{C}_{6} \mathrm{H}_{5}$

Figure 6. Synthesis of S-substituted derivatives of 5-thio-3-Ar-4-phenyl-4H-1,2,4-triazole [6]

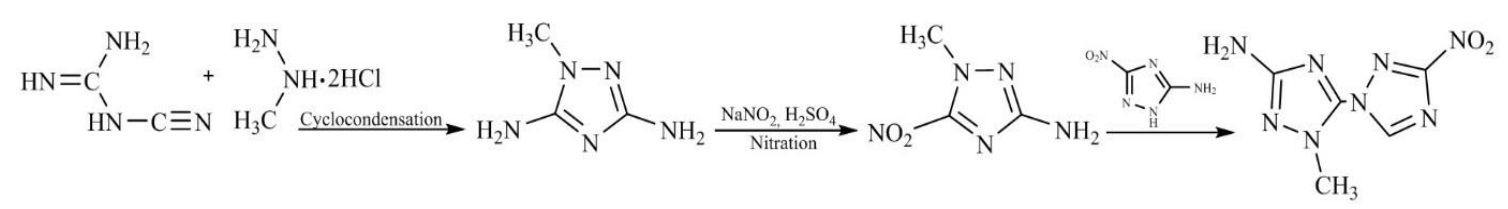

Figure 7. Synthetic route to 1,3-bi-1,2,4-triazole-5,5-diamine derivatives [7]

Taking into account that the scientific work was aimed at studying the energy properties of the molecule, it should be noted that its biological potential remains appropriate.

Due to the simple synthesis of available reagents and potentially biologically active functional groups of the molecule combined with two 1,2,4-triazole cycles, this compound and its synthetic analogues can be recommended for further pharmacological screening.

The authors [8] also developed and synthesized a series of derivatives of the 1,2,4-triazole heterocyclic system (Fig. 8). Their structures were proved using modern analytical methods. Biological effects (antimicrobial/antifungal) were evaluated in vitro. A BAC with a methoxyphenyl substitute in position 5 and a chlorophenyl fragment showed the highest activity [8]. 
Compounds that had a methoxyphenyl fragment showed the most powerful activity against Staphylococcus aureus. Synthesized BACs showed an antifungal effect against Candida albicans. Studies also showed that they can act as inhibitors of Mycobacterium fortuitum. The synthesized compounds can be useful as medium-to high-level disinfectants or antiseptics. They are non-toxic to the skin/mucous membranes.<smiles>[R]c1ccc(-c2n[nH]c(N)n2)cc1</smiles><smiles>[R]c1cccc(/C=N/c2nc(-c3ccccc3)n[nH]2)c1</smiles><smiles>[R]c1ccc([C@@H]2SC([Y17])(c3ccccc3)C(=O)N2c2nc(-c3ccccc3)n[nH]2)cc1</smiles>

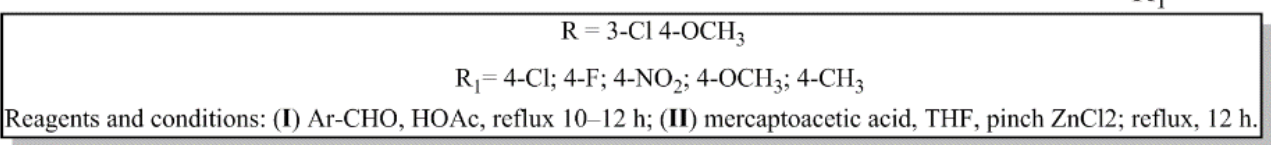

Figure 8. Synthesis of some new 4-thiazolidinones [8]

The conducted studies of scientists [9] indicate the prospects for using 1,2,4-triazole derivatives as excipients in the manufacture of dosage forms. The authors synthesized a series of 1,2,4-triazoles with a 3,4,5-trimethoxyphenyl radical and substituents in position 4 (Fig. 9). The structure is confirmed by a complex of modern analytical methods. Prospects for further research for scientists [9] are the high antimicrobial and antifungal effects of ylidenhydrazides in combination with the 1,2,4-triazole core.

The scientific work of the author [10] confirms the relevance of the direction. High rates of antimicrobial and antifungal activity in compounds with 1,2,4-triazole nucleus and 3,4,5trimethoxyphenyl substituent are shown. Therefore, compounds in scientific work [9] are relevant in terms of finding BAC.<smiles>[R]c1ccc(/C=N/n2c(S)nnc2-c2cc(OC)c(OC)c(OC)c2)cc1</smiles>

Figure 9. Synthesis of of 1,2,4-triazoles with a 3,4,5-trimethoxyphenyl radical and substituents in position 4 [9] 
The authors [11] developed and created a number of new myrtenal derivatives with a 1,2,4triazole core (Fig. 10). The derivatives were synthesized by multi-stage reactions to produce powerful BACs. The structures of compounds were confirmed using modern analytical approaches.

The antifungal activity of synthesized BACs against various strains of pathogenic fungi was evaluated for compounds taken at a dose of $50 \mathrm{~g} / \mathrm{ml}$. Compounds with isopropyl, ethyl, and orthonitrophenyl radicals (Fig. 10.) showed activity with an inhibition rate of more than $96.3 \%$ against Physalospora piricola. Azoxystrobin showed less activity than the synthesized compounds [11]. Inhibition of the control group was no more than $96.0 \%$ [11].

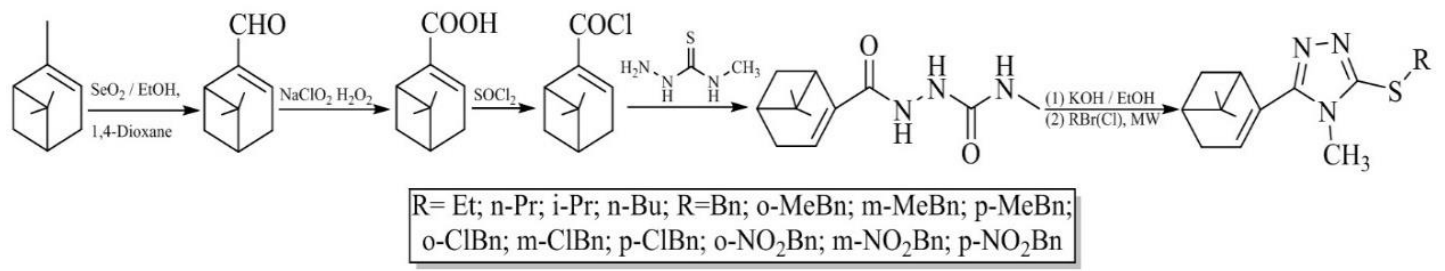

Figure 10. Synthesis of thioethers based on 5-R-4-methyl-1,2,4-triazole [11]

Scientists [12] paid great attention to the synthesis of 3-thio-1,2,4-triazoles with subsequent conversion to the corresponding S-glucosides. The compounds were created by combining $D$-glucose with thiogroups of 3-thio-4- $R-5$ (2'-aminophenylen substituted)-1,2,4-triazoles (Fig. 11). The structure of the compounds was determined by IR, UV, and ${ }^{1} \mathrm{H},{ }^{13} \mathrm{C}$ )-NMR spectrometry. The initial compounds and the $S$-glycoside representative were tested in vitro for Gram-positive and Gram-negative bacteria [12]. They showed considerable activity. Amikacin was used as a standard.

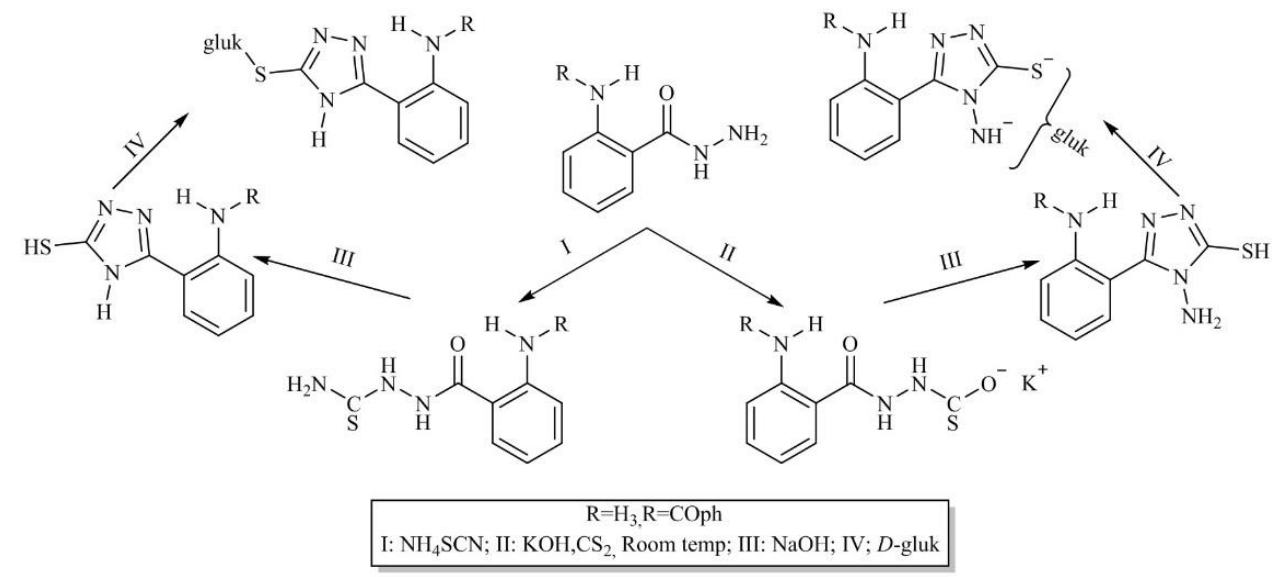

Figure 11. Synthesis of N- and S-triazologlycosides [12]

The study by scientists [13] describes the synthesis and study of 3-hydroxy-2-naphtholine hydrazide derivatives (Fig. 12). Thiosemicarbazide derivatives were synthesized by the interaction of 3- 
hydroxy-2-naphthoid hydrazide and the corresponding isothiocyanates. Thiones were synthesized by Alkaline cyclization of the corresponding thiosemicarbazides in an alkaline medium. ${ }^{1} \mathrm{H},{ }^{13} \mathrm{C}-\mathrm{NMR}$ spectrometric analysis established the structure of the BAC. Antimicrobial screening showed a high antibacterial effect against gram-positive bacteria. Cefuroxime was half as active as synthesized BACs. Ampicillin was 4 times less active than the synthesized analogues [13].

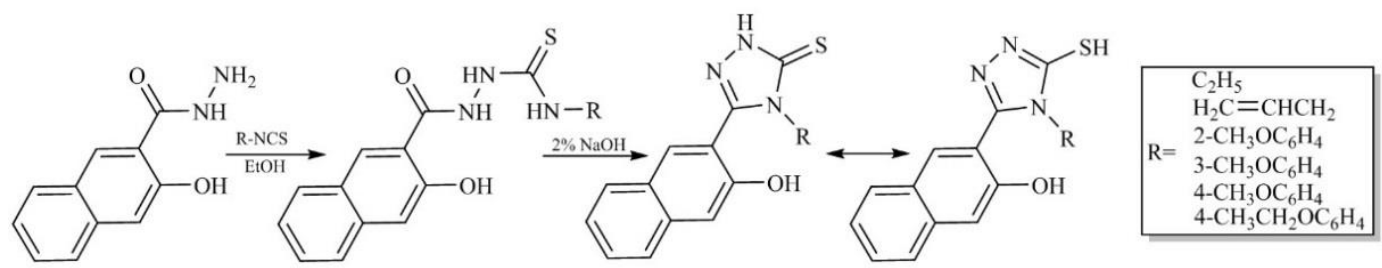

Figure 12. Synthesis scheme of naphtoid-1,2,4-triazole compounds [13]

3-Thio-1,2,4-triazole derivatives attracted attention of the scientists [14] due to their perspective in biological research. Alkyltio-1,2,4-triazoles have three nucleophilic centers ready to react with electronoacceptors. Thus, isomeric forms of benzylsulfanyl-1,2,4-triazole were synthesized with various dihaloalkanes (Fig. 13). Regional selectivity was determined by X-ray crystallography and NMR.

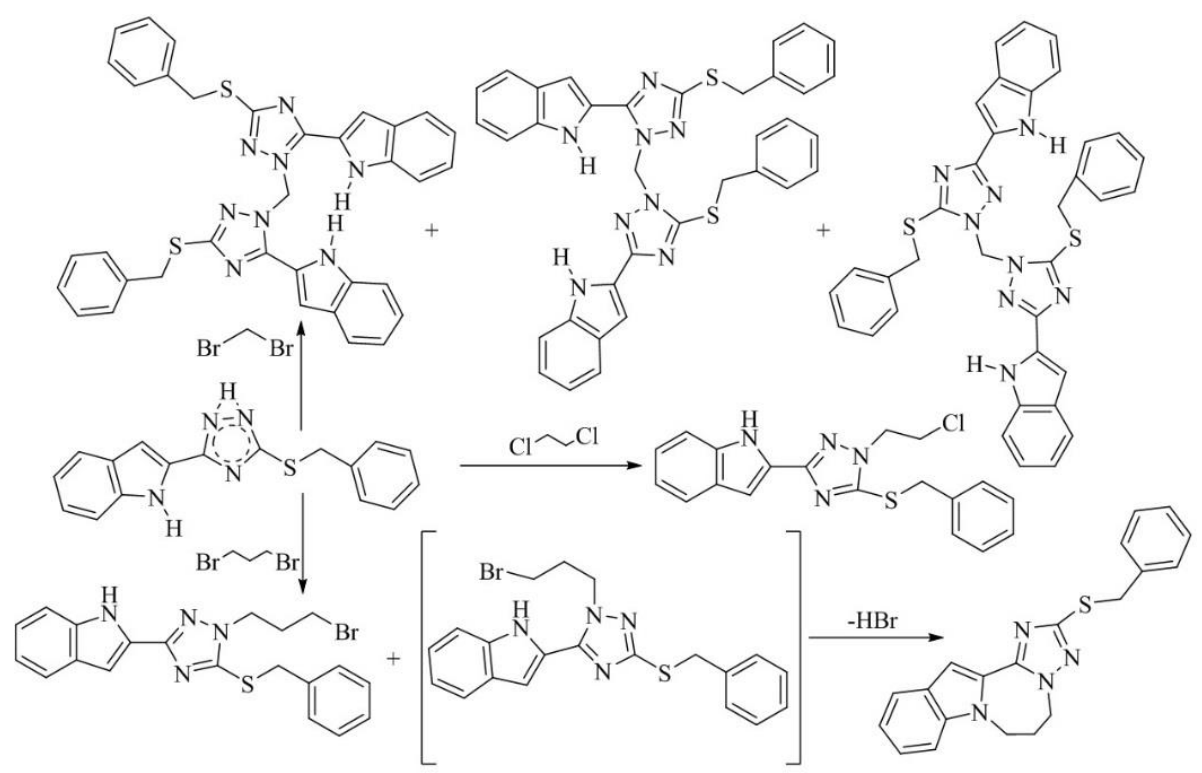

Figure 13. Products obtained from reaction of dihaloalkanes and 1,2,4-triazole derivatives [14]

When S-substituted forms of thiotriazoles interact with various alkylating agents, only N1 and N2 attack electron-acceptor carbon atoms. Mainly molecules with the participation of N2 atoms are formed.

In a study [15], a number of new derivatives of hydrazone and 1,2,4-triazole sulfonamide were synthesized. Initially, the authors treated 3-thio-1,2,4-triazoles with ethyl acetate to obtain thioethers, which were subsequently converted to hydrazides by a hydrogenolysis reaction. The synthesized 
hydrazides were converted into the formula of the corresponding sulfonamides and hydrazones. The structure of the synthesized compounds was characterized by 1H, 13C-NMR spectrometry. Elemental composition was established by elemental analysis.

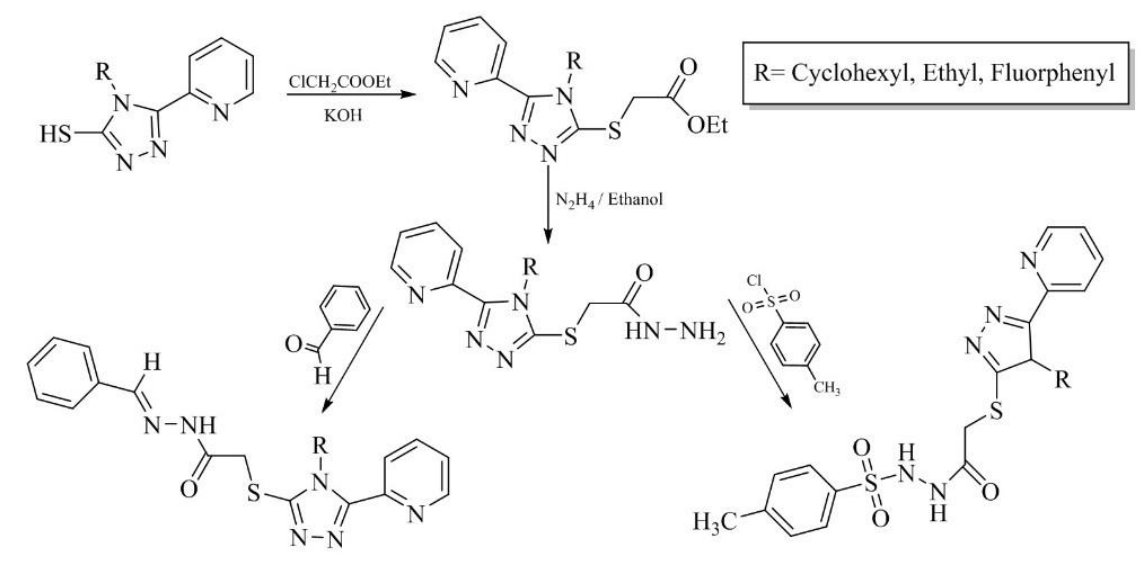

Figure 14. Synthesis of derivatives 1,2,4-triazole, transformated to hydrazones and sulphonamides

In addition, the anticoagulant effect was studied for synthesized BACs. Synthesized compounds increased the time of plasma rectification and bleeding. Screening of synthesized compounds proves that this matrix can be used in medical practice for more detailed research.

The authors [16] reported the synthesis of new derivatives of 1,2,4-triazole with benzodioxane in the fifth position. The desired amidomethylthio derivatives were synthesized by replacing the potassium salt of triazolotyol with various primary arylalkylamines [16] (Fig. 15).

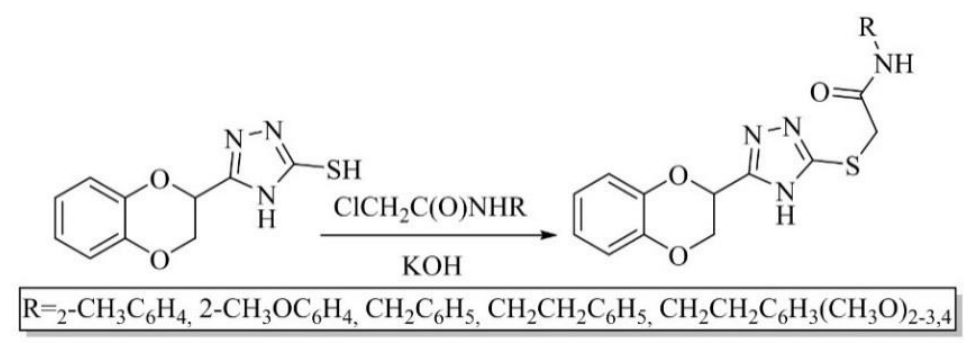

Figure 15. Transformation of 1,4-benzodioxanyl-1,2,4-triazoles [16]

According to the authors [16], derivatives of 5-(1,4-benzodioxanyl)-1,2,4-triazole-3-thiol have antitumor effects. The compounds also showed antimicrobial and antiviral effects. The authors also synthesized triheterocyclic compounds (Fig. 16). The individuality and structure were proved by modern analytical methods.

The authors [17] synthesized a number of compounds based on 1,2,4-triazole, combining heterocyclic systems of benzofuran, pyrazole and quinoline (Fig. 17). The elemental composition of the synthesized BACs was determined by elemental analysis. 1H, 13C-NMR spectrometry allowed to 
establish the structure which was finally confirmed by mass spectrometry. Antimicrobial action indicators were established for synthesized BACs. Chloramphenicol, as a standard, showed the worst result.

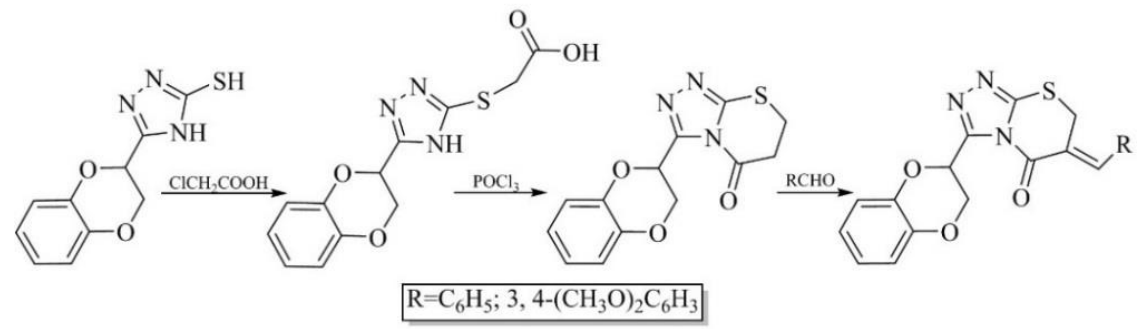

Figure 16. Obtaning triheterocyclic structures, 1,2,4-triazole derivatives [16]

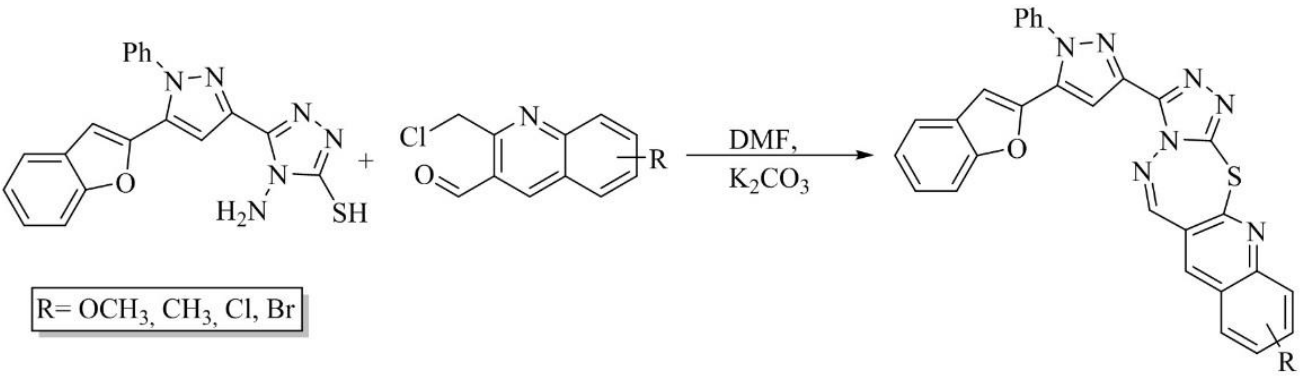

Figure 17. Synthesis of compounds based on 1,2,4-triazole, combining heterocyclic systems of benzofuran, pyrazole and quinoline [17]

\section{Review of Complex Formation of 1,2,4-triazole Derivatives and Prospects for Their Application}

Scientists [18] investigated five new complex compounds based on the heterocyclic system of 1,2,4-triazole and palladium. Enantiomeric pairs turned out to be anti-cancer agents. Antiproliferative properties were inherent in all synthesized complexes. In particular, this was expressed in the deactivation of MCF7 cells. The study revealed that the enantiomers of all synthesized complexes show almost the same activity, which indicates the absence of the effect of chirality on their antiproliferative activity. It is important to emphasize that the compounds show very low toxicity to non-cancerous cell lines.[18].

The authors [19] synthesized two complexes with complexing agent $\mathrm{Cu}$ (II). Scientists [19] used Azocenol as a ligand of complex. All complexes show greater activity for the inhibition of fungi than the Azocenol, which indicates the potential use of these complexes as antifungal agents. In addition, the complex of $\mathrm{Cu}(\mathrm{II}),\left[\mathrm{CuL}_{4} \cdot\left(\mathrm{H}_{2}\right)_{2}\right] \cdot 2 \mathrm{NO}_{3} \cdot 2 \mathrm{CH}_{3} \mathrm{OH} \cdot$ has a stronger antifungal activity than $\left[\mathrm{CuL}_{2} \cdot\right.$ $\left.\left(\mathrm{CH}_{3} \mathrm{COO}^{-}\right)_{2}\right][19]$.

In studies [20], a water-soluble diamino-1,2,4-triazole complex with complex ion $\mathrm{Cu}$ (II) was obtained, corresponding to the structure indicated in Figure 18. The Cu-triazole complex in solution is very unstable. The structure of the complex compound depends on the exact state of the reaction. It is 
important to note that copper chelate complexes are important because they can be used to increase the formation of collagen and connective tissues of the skin, bones and cartilages.

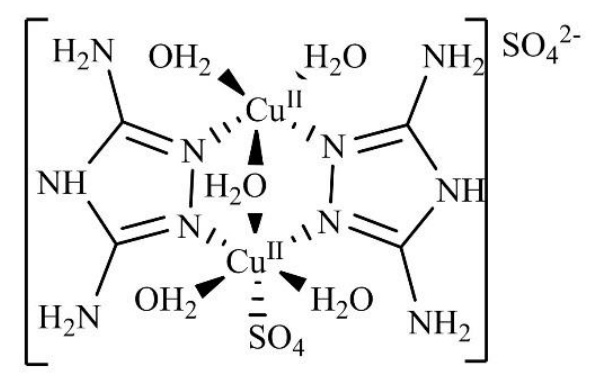

Figure 18. The structure of diamino-1,2,4-triazole complex with complex ion $\mathrm{Cu}$ (II) [20]

Continuing the study of complex compounds [21], the authors investigated new Anderson-type polyoxometalates and organometallic complexes based on octamolybdates with triazole ligands. The basis for the creation of complexes included a combination with Co (II). Theoretically, these compounds can be used to enhance the synthesis of vitamin B12 in the human body.

The researchers [22] proposed two coordination complexes Fe [22] (Fig. 19), which combine two different types of ligands.

From the point of view of researches of these complexes on biological activity, it is possible to note with confidence that they have a great potential, considering redox processes of an organism.
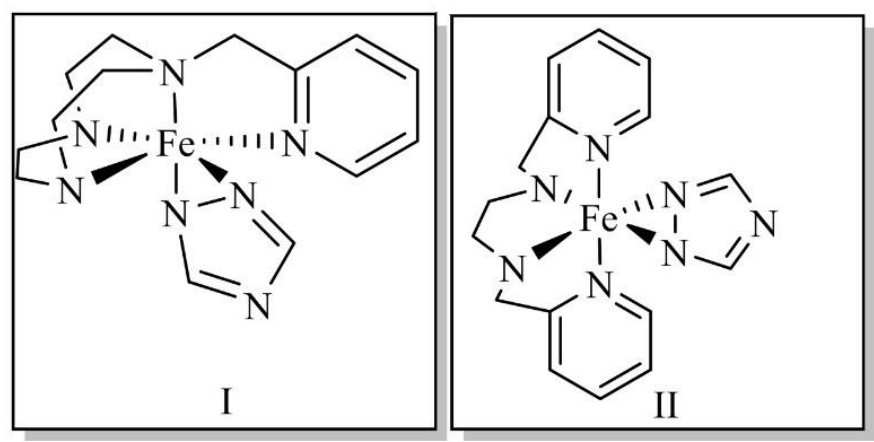

Figure 19. Structures of the Fe complex with 1,2,4-triazole ligands [22]

Researchers [23] studied the adsorption of alkylthio derivatives of 1,2,4-triazole on the surface of metal plates, which led to the formation of complex compounds. Interpolating research into the medical and pharmaceutical fields, it should be noted that these compounds, due to their anticorrosive effect, may be useful because they can affect the oxidative function.

Complexes obtained by the authors [24] (Fig. 20) can be a promising material for the study of biological properties of 1,2,4-triazole compounds. 
A series of metal complexes of Lanthanum and Thorium were synthesized by the authors [25] using 1,2,4-triazole ligands. Ligands were created by condensation of 1,2,4-triazole and coumarin derivatives. The structure of the complexes was proved by elemental analysis and spectroscopic methods. All synthesized compounds are soluble in dimethylformamide and dimethylsulfoxide. All ligands and their complexes were also tested for their antibacterial (Escherichia coli, Staphylococcus aureus, Staphylococcus pyogenes and Pseudomonas aeruginosa) [25] and antifungal properties. [25].<smiles>O=C[NH+]([O-])c1nc[nH]n1</smiles><smiles></smiles>

Figure 20. Experimentally-determined 1,2,4-triazole complexes [24]

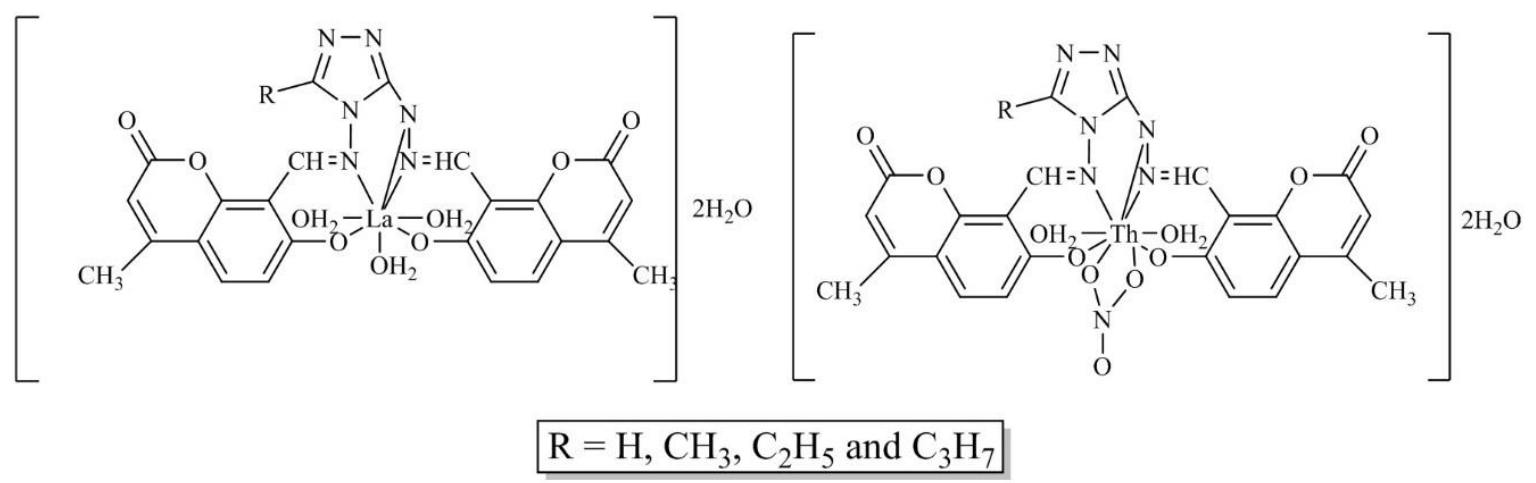

Figure 21. Complexes with 1,2,4-triazole ligands and central ions of La (Th) [25]

The authors [26] investigated a number of complex compounds based on 1,2,4-triazole. According to the researches, the obtained complexes have a fairly high resistance and are quite resistant to light.

After analyzing a number of scientific studies of scientists [1-32], we can conclude that studies of 1,2,4-triazole derivatives occupy an important place in the Ukrainian pharmaceutical industry [2732]. The articles show that scientists have a fairly broad approach to the modification of 1,2,4-triazole heterocycle [27-30]. Aspects of studies of the biological action of 1,2,4-triazole derivatives are also covered. The scientists pay special attention to histological [33] and pharmacokinetic studies [34], studies of actoprotective action [35] and other types of screening tests [36-40]. Based on the heterocyclic system of 1,2,4-triazole, many drugs with antifungal, antibacterial, antioxidant and hepatoprotective effects have been developed and introduced into medical practice. 
As a result of the review, a vector of further research has been formed. It represents the formation of complex structures from bioactive derivatives of 1,2,4-triazoles.

To create bioactive structures, it is appropriate to combine 1,2,4-triazoles with heterocyclic systems. As a rule, biological activity depends on the number of electron-donor atoms in the heterocyclic system. The processed data allows to conclude that it is appropriate to emphasize the creation of new Schiff bases, new thioacetic acids and their water-soluble salts.

According to the methods presented in the review, it is proposed to investigate the coordination complexes and to correlate between the new coordination compounds and salts of 1,2,4-triazole-3thioacetic acids, with the same cations as in the complex compounds.

\section{ACKNOWLEDGEMENT}

The team of authors expresses their sincere gratitude to Zaporizhzhia State Medical University for the opportunity to perform the scientific studies within the walls of the university.

\section{AUTHOR CONTRIBUTIONS}

Conception: Y.G.S.; Design: T.M.K.; Supervision: Y.G.S.; Resources: F.A.Z.; Analysis and/or interpretation: Y.G.S.; Literature search: Y.G.S., T.M.K.; F.A.Z.; Writing manuscript: Y.G.S.; Critical review: Y.G.S.

\section{CONFLICT OF INTEREST}

The authors declare no conflict of interest.

\section{REFERENCES}

1. Khan, S., Imam, S., Ahmad, A., Basha, S., Husain, A. (2018). Synthesis, molecular docking with COX 1\& II enzyme, ADMET screening and in vivo anti-inflammatory activity of oxadiazole, thiadiazole and triazole analogs of felbinac. Journal Of Saudi Chemical Society, 22(4), 469-484. [CrossRef]

2. Barbuceanu, S., Draghici, C., Barbuceanu, F., Bancescu, G., Saramet, G. (2015). Design, synthesis, characterization and antimicrobial evaluation of some heterocyclic condensed systems with bridgehead nitrogen from thiazolotriazole class. Chemical And Pharmaceutical Bulletin, 63(9), 694-700. [CrossRef]

3. Mioc, M., Avram, S., Bercean, V., Kurunczi, L., Ghiulai, R. M., Oprean, C., Soica, C. (2018). Design, synthesis and biological activity evaluation of S-substituted 1H-5-mercapto-1,2,4triazole derivatives as antiproliferative agents in colorectal cancer. Frontiers in chemistry, 6, 119. [CrossRef] 
4. Nastasă, C., Vodnar, D., Ionuţ, I., Stana, A., Benedec, D., Tamaian, R., Onica, O., Tiperciuc, B. (2018). Antibacterial evaluation and virtual screening of new thiazolyl-triazole schiff bases as potential DNA-gyrase inhibitors. International Journal of Molecular Sciences, 19(1), 222. [CrossRef]

5. Karbalaei, M., Seifi, M., Sheibani, H. (2014). Regioselective ring opening of 2,2-dicyanooxiranes by 1,3-dinucleophiles in the presence of Lewis acids such as bismuth(III) nitrate pentahydrate $\left[\mathrm{Bi}\left(\mathrm{NO}_{3}\right)_{3} \cdot 5 \mathrm{H}_{2} \mathrm{O}\right]$ and zirconium(IV) chloride $\left(\mathrm{ZrCl}_{4}\right)$. Research on Chemical Intermediates, 41(7), 4679-4686. [CrossRef]

6. Ur-Rehman, A., Nafeesa, K., Athar Abbasi, M., Zahra Siddiqu, S., Rasool, S., Adnan Ali Shah, S., Ashraf, M., Lodhi, M.A., Khan, F.A., Jahan, B. (2018). S-substituted derivatives of 1,2,4triazol-3-thiol as new drug candidates for type II diabetes. Turkish Journal of Chemistry, 42(3), 652-67. [CrossRef]

7. Luo, J., Liu, Y., Liu, Y., Wang, J., Chai, T., \& Yuan, J., Chang, S., Yu, Y., Jing, S., Ma, H. (2017). Synthesis and theoretical studies of a new insensitive explosive, 2'-methyl-3-nitro-2'H[1,3'-bi(1,2,4-triazole)]-5,5'-diamine. Central European Journal of Energetic Materials, 14(2), 269-280. [CrossRef]

8. Ahmed, S., Zayed, M., El-Messery, S., Al-Agamy, M., Abdel-Rahman, H. (2016). Design, Synthesis, Antimicrobial Evaluation and Molecular Modeling Study of 1,2,4-Triazole-Based 4Thiazolidinones. Molecules, 21(5), 568. [CrossRef]

9. Ali, G., El-Hiti, G., Tomi, I., Haddad, R., Al-Qaisi, A., Yousif, E. (2016). Photostability and performance of polystyrene films containing 1,2,4-triazole-3-thiol ring system schiff bases. Molecules, 21(12), 1699. [CrossRef]

10. Sameliuk, Y. (2016). PhD Thesis. Synthesis and study of biologically active 1,2,4-triazoles-3thione derivatives, which contain methoxyphenyl substituents. Zaporizhzhia State Medical University. [CrossRef]

11. Lin, G., Duan, W., Yang, L., Huang, M., Lei, F. (2017). Synthesis and antifungal activity of novel myrtenal-based 4-methyl-1,2,4-triazole-thioethers. Molecules, 22(2), 193. [CrossRef]

12. Benhammadi, S., Salimairaten, S., Othman, A. (2016). Synthetic studies and antibacterial activity of nucleobases and their N- and S-glucosidesfrom 2-amino benzoic acid and its benzamido derivatives. Oriental Journal of Chemistry, 32(5), 2567-2576. [CrossRef]

13. Popiołek, Ł., Paruch, K., Patrejko, P., Biernasiuk, A., Wujec, M. (2016). New 3-hydroxy-2naphthoic hydrazide derivatives: thiosemicarbazides and 1,2,4-triazole-3-thiones, their synthesis and in vitro antimicrobial evaluation. Journaltf the Iranian Chemical Society, 13(10), 1945-1951. [CrossRef]

14. Boraei, A., El Ashry, E., Duerkop, A. (2016). Regioselectivity of the alkylation of S-substituted 1,2,4-triazoles with dihaloalkanes. Chemistry Central Journal, 10, 22. [CrossRef]

15. Khalid, W., Badshah, A., Khan, A., Nadeem, H., Ahmed, S. (2018). Synthesis, characterization, molecular docking evaluation, antiplatelet and anticoagulant actions of 1,2,4 triazole hydrazone and sulphonamide novel derivatives. Chemistry Central Journal, 12, 11. [CrossRef] 
16. Sargsyan, A., Avakyan, A., Vartanyan, S., Stepanyan, G., Paronikyan, R. (2018). Synthesis of new 1,4-benzodioxanyl-1,2,4-triazole derivatives. Russian Journal of General Chemistry, 88(4), 839-842. [CrossRef]

17. Idrees, M., Kola, S., Siddiqui, N. (2018). Synthesis of novel series of quinolino[3,2f] $[1,2,4]$ triazolo[3,4-b][1,3,4]-thiadiazepines derivatives incorporated with 3-[5-(benzofuran-2yl)-1-phenyl-1h-pyrazol-3-yl] moiety as potent antimicrobial agent. Asian Journal of Chemistry, 30(9), 2129-2133. [CrossRef]

18. Kumar, A., Naaz, A., Prakasham, A., Gangwar, M., Butcher, R., Panda, D., Ghosh, P. (2017). Potent anticancer activity with high selectivity of a chiral palladium $n$-heterocyclic carbene complex. ACS Omega, 2(8), 4632-4646. [CrossRef]

19. Li, J., Liu, H., Guo, Z., Yang, M., Song, J., Ma, H. (2018). Two Cu(ii)-triadimenol complexes as potential fungicides: synergistic actions and DFT calculations. RSC Advances, 8(6), 2933-2940. [CrossRef]

20. Van Dijk, B., Hofmann, J., Hetterscheid, D. (2018). Pinpointing the active species of the $\mathrm{Cu}$ (DAT) catalyzed oxygen reduction reaction. Physical Chemistry Chemical Physics, 20(29), 19625-19634. [CrossRef]

21. Wang, X., Bai, X., Lin, H., Sun, J., Wang, X., Liu, G. (2018). A series of new polyoxometalatebased metal-organic complexes with different rigid pyridyl-bis(triazole) ligands: assembly, structures and electrochemical properties. RSC Advances, 8(40), 22676-22686. [CrossRef]

22. Popov, I., Davis, B., Mukundan, R., Batista, E., Yang, P. (2019). Catalyst-inspired charge carriers for high energy density redox flow batteries. Frontiers In Physics, 6, 141. [CrossRef]

23. Arkhipushkin, I., Shikhaliev, K., Potapov, A., Sapronova, L., Kazansky, L. (2017). Inhibition of brass (80/20) by 5-mercaptopentyl-3-amino-1,2,4-triazole in neutral solutions. Metals, 7(11), 488. [CrossRef]

24. Del Bene, J., Elguero, J., Alkorta, I. (2018). Complexes of $\mathrm{CO}_{2}$ with the azoles: tetrel bonds, hydrogen bonds and other secondary interactions. Molecules, 23(4), 906. [CrossRef]

25. Bagihalli, G., Patil, S., Badami, P. (2009). Synthesis, spectral characterization, in vitro microbial and cytotoxic studies of lanthanum(III) and thorium(IV) complexes with 1,2,4-triazole Schiff bases. Journal of Enzyme Inhibition And Medicinal Chemistry, 24(3), 730-741. [CrossRef]

26. Chen, D., Zheng, Y., Shi, D., Fang, S. (2020). An acid-base resistant polyoxometalate-based metal-organic framework constructed from $\left\{\mathrm{Cu}_{4} \mathrm{Cl}\right\} 7+$ and $\left\{\mathrm{Cu}_{2}\left(\mathrm{CO}_{2}\right)_{4}\right\}$ clusters for photocatalytic degradation of organic dye. Journal of Solid State Chemistry, 287, 121384. [CrossRef]

27. Hulina, Y., Kaplaushenko, A. (2017). Synthesis and physical-chemical properties of 6-(5- $(1 \mathrm{H}-$ tetrazole-1-ylmethyl)-4-R-1,2,4-triazole-3-ylthio)pyridin-3-amines and 6-((5-(1H-tetrazole-1yl)methil-4-R-1,2,4-triazole-3-ylthio)pyridin-3-yl)-(alk,ar,heter)ylmethanimines. Zaporozhye Medical Journal, 19(1), 100-104. [CrossRef]

28. Frolova, Y. (2020). Design, synthesis, antimicrobial and antifungal activities of new 1,2,4-triazole derivatives containing $1 \mathrm{H}$-tetrazole moiety. Journal of Faculty of Pharmacy of Ankara University, , 44(1), 70-88. [CrossRef] 
29. Shcherbyna, R. (2019). Microwave-assisted synthesis of some new derivatives of 4-substituted3-(morpholinomethyl)-4H-1,2,4-triazole-5-thioles. Journal of Faculty of Pharmacy of Ankara University, , 43(3), 220-229. [CrossRef]

30. Shcherbyna, R., Parchenko, V., Varynskyi, B., Kaplaushenko, A. (2019). The development of HPLC-DAD method for determination of active pharmaceutical ingredient in the potassium 2((4-amino-5-(morpholinomethyl)-4H-1,2,4-triazol-3-yl)thio)acetate substance. Current Issues In Pharmacy And Medical Sciences, 32(1), 5-9. [CrossRef]

31. Varynskyi, B., Kaplaushenko, A. (2019). The Force degradation study of the morpholinium 2((4-(2-methoxyphenyl)-5-(pyridin-4-yl)-4h-1,2,4-triazol-3-yl)thio)acetate. Indonesian Journal of Pharmacy, 30(1), 25-34. [CrossRef]

32. Danilchenko, D., Safonov, A. (2017). Diuretic activity of 2-((4-amino-5-R-4H-1,2,4-triazole-3yl)thio)acetohydrazides. Zaporozhye Medical Journal, 19(4), 517-519. [CrossRef]

33. Vashchyk, Y., Shcherbyna, R., Parchenko, V., Bushueva, I., Gutyj, B., Fotina, H., Stronskyi, Y. (2020). Histological study of a corrective influence of a compound potassium 2-((4-amino-5(morpholinomethyl)-4H-1,2,4-triazol-3-yl) thio)acetate (pkr-173) on the state of chicken's liver under infection by pseudomonas aeruginosa. Journal of Faculty of Pharmacy of Ankara University, 44(1), 1-17. [CrossRef]

34. Shcherbyna R. (2020). An investigation of the pharmacokinetics and potential metabolites of potassium 2-((4-amino-5-(morfolinometyl)-4H-1,2,4-triazol-3-yl)thio) acetate on rats. Journal of Faculty of Pharmacy of Ankara University , 44(2), 233-241. [CrossRef]

35. Safonov, A. A., \& Nevmyvaka, A. V. (2020). Actoprotective activity research of 2-((5-(2bromophenyl)-4-substituted-4H-1,2,4-triazole-3-yl)thio)acetates. . Current issues in pharmacy and medicine: science and practice, 13(2), 260-264. [CrossRef]

36. Ihnatova, T., Kaplaushenko, A., Frolova, Y., Pryhlo, E. (2021). Synthesis and antioxidant properties of some new 5-phenethyl-3-thio-1, 2, 4-triazoles. Pharmacia, 68, 129-133. [CrossRef]

37. Gotsulya, A., Zazhzharskiy, V., Davidenko, P. (2020). Features of experimental modeling of tuberculosis in guinea pig with the participation of N'-(2-(5-((thephylline-7-yl)methyl)-4-R-1,2,4triazole- ylthio)acethyl)isonicotinohydrazide. Ukrainian Journal of Ecology, 10(4), 191-194. [CrossRef]

38. Hotsulia, A.S., Fedotov, S.O. (2020). Synthesis and properties of 2-(4-phenyl-5-(((5phenylamino-1,3,4-thiadiazole-2-yl)thio)methyl)-1,2,4-triazole-3-yl)thio)ethanoic acid and its salts. Current issues in pharmacy and medicine: science and practice, 3, 330-336. [CrossRef]

39. Zozulynets, D.M., Kaplaushenko, A.G., Korzhova, A.S. (2021). The synthesis of 4-amino-5(quinolin-2-yl)-4H-1,2,4-triazole-3-thiol and its interaction with aldehydes. Journal of Organic and Pharmaceutical Chemistry, 19(1(73)), 48-52. [CrossRef]

40. Varynskyi, B., Kaplaushenko, A. (2020). Metabolism study of morpholinium 2-((4-(2methoxyphenyl)-5-(pyridin-4-yl)-4H-1,2,4-triazole-3-yl)thio)acetate. Current Issues in Pharmacy and Medical Sciences, 33(2), 72-75. [CrossRef] 